\title{
APPLICATION OF PHENYLALANINE AND TYROSINE AS ELUENTS IN ION CHROMATOGRAPHY. THE SORPTION OF THE ELUENT INGREDIENTS IN THE SUPPRESSOR COLUMN
}

\author{
(Presented by J. Kann)
}

Recently, amino acids were used as eluents in suppressed ion chromatography (IC) $\left[{ }^{1,2}\right]$, whereas better sensitivity was achieved in comparison with the most widespread eluent, the carbonate one.

In aqueous solutions amino acids exist in different ionic forms, depending on the $\mathrm{pH}$ of the solution $\left[{ }^{2}\right]$ :

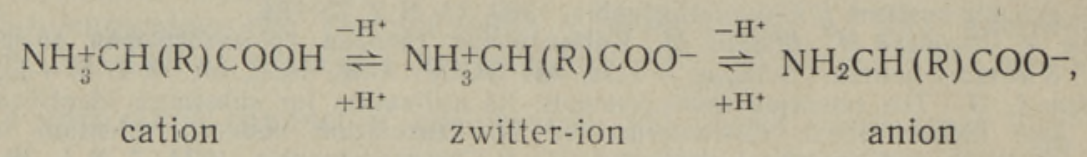

where $\mathrm{R}$ is a substituent. To eluate the sample anions such conditions have been chosen under which amino acid mainly exists as an anion.

The cation exchange processes in the suppressor column were interpreted in two different ways.

J. P. Ivey [ $\left.{ }^{1}\right]$, using the $\mathrm{Na}$ salt of $2(\mathrm{~N}$-morpholino) ethanesulphonic acid as an eluent, assumed that by passing the suppressor column the sodium ion will be replaced by hydrogen and the zwitter ionic form of the $2(\mathrm{~N}$-morpholino) ethanesulphonic acid is formed. At their isoelectric point zwitter ions do not respond to the conductometric detection and the sample anions, which elute in the acid form, are detected in a low-conductivity background.

O. A. Shpigun et al. $\left[{ }^{2}\right]$, using the $\mathrm{Na}$ salts of glycine, $\beta$-alanine, $p$-aminobenzoic acid etc. as eluents presumed that in the suppressor column the amino acid eluent is totally sorbed on the cation exchanger:

$$
\begin{aligned}
& ]-\mathrm{H}^{+}+\mathrm{Na}^{+}+\mathrm{NH}_{2} \mathrm{CH}(\mathrm{R}) \mathrm{COO}^{-}=\right]-\mathrm{Na}^{+}+\mathrm{NH}_{3}^{+} \mathrm{CH}(\mathrm{R}) \mathrm{COO}^{-}, \\
& ]-\mathrm{H}^{+}+\mathrm{NH}^{+} \mathrm{CH}(\mathrm{R}) \mathrm{COO}^{-}+\mathrm{OH}^{-}=\right]-\mathrm{NH}_{3}^{+} \mathrm{CH}(\mathrm{R}) \mathrm{COO}^{-}+\mathrm{H}_{2} \mathrm{O},
\end{aligned}
$$

where ]- is an ion-exchange site. The sample anions elute in the acid form and are detected in the background of deionized water.

Owing to the lack of unanimity in this problem, it is important to study the composition of that kind of eluent that flows out of the suppressor column.

In a previous paper of this series $\left.{ }^{3}\right]$ the eluation parameters of tyrosine (Tyr) and phenylalanine (Phe) eluents were studied. The aim of the present paper is to investigate the sorption processes of the amino acid eluents used in the suppressor column to clarify which ions, if any, are passing the suppressor column in various stages of its capacity exhaustion. For this purpose, IC methods were tested to determine eluent ingredients. 


\section{Experimental}

The IC system consisted of the following elements: a pump at a flow rate of $1.5 \mathrm{ml} / \mathrm{min}$, injector with a $0.1 \mathrm{ml}$ sample loop, the separator and the suppressor column, a detector and a recorder.

All solutions were prepared in degassed bidistilled water and analytical grade reagents (Reakhim) were used.

For the determination of Phe and Tyr a non-suppressed IC system with a $55 \times 4 \mathrm{~mm} \mathrm{I}$. D. separator column, packed with $0.026 \mathrm{mmol} / \mathrm{g}$ of anion-exchange resin [4], fraction $40-63 \mu \mathrm{m}$, and spectrophotometric detector from a Milikhrom liquid chromatograph were used. The eluent was $0.5 \mathrm{mM} \mathrm{Na}_{2} \mathrm{SO}_{4}$, pH 10 (prepared by adding $0.1 \mathrm{M} \mathrm{NaOH}$ ). Amino acids were detected at a wavelength of $222 \mathrm{~nm}$ and 0.2 AUFS.

The sodium ions were determined using the non-suppressed IC system with $150 \times 2 \mathrm{~mm}$ I. D. separator column, packed with a low-capacity cation-exchange resin, synthesized at the Institute of Chemistry, Estonian Academy of Sciences, and a conductometric detector with a cell constant of $3 \mathrm{~cm}^{-1}(293 \mathrm{~K})$. The sodium ions were detected by the indirect method, using $3 \mathrm{mM} \mathrm{HNO}_{3}$ as eluent.

Evaluation of the chromatograms was performed by measuring the peak heights. For the calibration plots the standard solutions with the Phe or Tyr concentration of $5,10,25,50$ and $100 \mathrm{ppm}$ and the $\mathrm{Na}^{+}$ concentration of $5,10,20,30$ and $40 \mathrm{ppm}$ were prepared.

The sorption processes in the suppressor column were studied by exhausting the cation-exchange capacity of the suppressor column. A short $60 \times 4 \mathrm{~mm}$ I. D. suppressor column, packed with a high-capacity cationexchange resin $\mathrm{KY}-2,3 \mathrm{mM}$ Phe $+4 \mathrm{mM} \mathrm{NaOH}$ eluent and a conductivity detector has been used. The eluate was collected as fractions, in which the concentration of Phe and $\mathrm{Na}^{+}$was measured.

\section{Results and discussion}

To measure the eluent ingredients concentration in the eluate fractions, IC methods have been tested.

In the alkaline medium of the eluent Phe mostly exists as a singlecharged anion $\left(\mathrm{C}_{6} \mathrm{H}_{5}-\mathrm{CH}_{2}-\mathrm{CH}\left(\mathrm{NH}_{2}\right)-\mathrm{COO}^{-}\right)$, but Tyr partly as a double-charged anion $\left.\left(-\mathrm{O}-\mathrm{C}_{6} \mathrm{H}_{4}-\mathrm{CH}_{2}-\mathrm{CH}\left(\mathrm{NH}_{2}\right) \mathrm{COO}^{-}\right){ }^{3}\right]$ and has to elute slower than Phe. In the conditions used to determine amino acids the average adjusted retention time for Phe was $1.27 \pm 0.05 \mathrm{~min}$ and for Tyr $3.26 \pm 0.06 \mathrm{~min}\left(\mathrm{t}_{\mathrm{o}}=0.50 \mathrm{~min}, n=6, P=0.95\right)$. The relative retention time $\alpha_{P h e}^{\text {Tyr }}=2.56$, resolution $R=1.32$ (all the values here and below were measured according to $\left.{ }^{5}\right]$ ). So the separation is sufficient for the simultaneous determination of the above amino acids (Fig. 1). The efficiency (expressed by the HETP value) was $0.98 \mathrm{~mm}$ for Phe and $1.14 \mathrm{~mm}$ for Tyr.

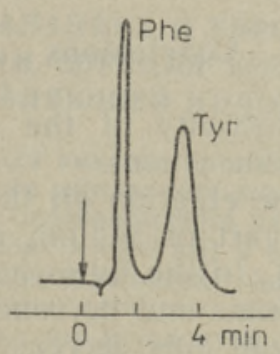

Fig. 1 The chromatogram of phenylalanine $(25 \mathrm{ppm})$ and tyrosine $(25 \mathrm{ppm})$ mixture. 
The calibration plots for Phe, Tyr and $\mathrm{Na}^{+}$were linear in the range of concentrations used.

Preliminary experiment showed that by using Phe or Tyr as eluents and a freshly regenerated suppressor column, no amino acid could be detected in the eluate. The eluation with the Phe $+\mathrm{NaOH}$ eluent (Phe was chosen for its better solubility than Tyr to accelerate the suppressor column capacity exhaustion, using the concentrated eluent) was continued until the base line on the chromatogram began to rise quickly (Fig. 2).

The effect of the eluate volume on its composition was determined by plotting the average concentration of Phe $\left(\mathrm{C}_{\mathrm{phe}}\right)$ and $\mathrm{Na}^{+}$ions $\left(\mathrm{C}_{\mathrm{Na}^{+}}{ }^{+}\right)$in the eluate fraction v.s. the total volume of the eluate $(V)$ (Fig. 3). The results showed that Phe was completely sorbed on the resin KY-2 in the first stage of the eluation process. Further eluation showed Phe to appear in the eluate and its concentration began to increase. The sodium ions were passing through the suppressor column already in the first stage of eluation $\left(\mathrm{C}_{\mathrm{Na}^{+}}{ }^{+}\right.$approx. $\left.1 \mathrm{ppm}\right)$. When Phe appeared in the eluate, the concentration of $\mathrm{Na}$ ions decreased below the detection limit. During further eluation $\mathrm{Na}^{+}$ions appeared in the eluate and their concentration began to increase.

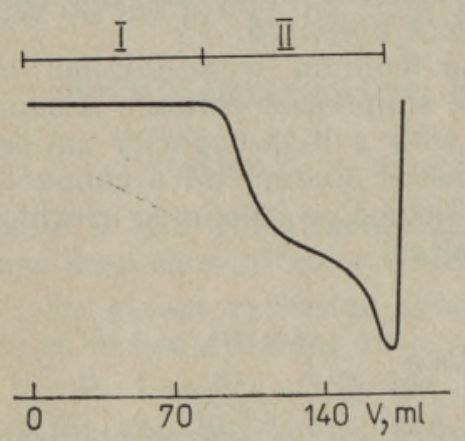

Fig. 2. Base line at the suppressor column cation-exchange capacity exhaustion.

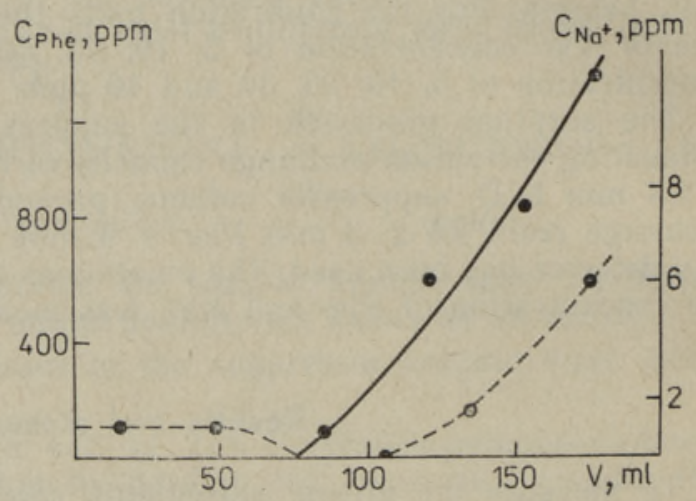

Fig. 3. The effect of the eluate volume on its composition $\left(-\mathrm{Phe},--\mathrm{Na}^{+}\right)$.

The results showed that under the conditions used the detection of anions could not be carried out in the background of the deionized water. That was also proved by the existence of a negative peak when bidistilled water was injected into the IC system as a sample. For quantitative analysis of anions only the first stage of eluation was suitable (Fig. 2, segment I) as the eluate composition ( $1 \mathrm{ppm} \mathrm{Na} \mathrm{Na}^{+} \approx 0.05 \mathrm{mM} \mathrm{NaOH}$ ) was constant and hence the background conductivity.

\section{Conclusions}

1. The background conductivity of the eluate changed during the eluation with the phenylalanine eluent.

2. In the first stage of the eluation all the amino acid was sorbed in the suppressor column, but part of sodium ions passed through it (the concentration approx. $1 \mathrm{ppm})$. In the following stage of the eluation phenylalanine appeared in the eluate and its concentration began to increase, but the concentration of sodium ions decreased below the detection limit. By continuing the eluation, the sodium ions again appeared in the eluate and their concentration began to increase. 
3. The quantitative determination of anions was possible in the first stage of eluation because the background conductivity was constant only there.

4. In the eluate, phenylalanine and tyrosine were determined by nonsuppressed anion chromatography, using a spectrophotometric detector. The same method, but using a cationic separator column and a conductivity detector was applied to the determination of sodium ions.

\section{REFERENCES}

1. Ivey, J., P. Zwitter ionic eluents for suppresséd ion chromatography // J. Chromatogr., 1984, 287, 128-132.

2. Shpigun, O. A., Voloshik, I. N., Zolotov, Yu. A. Application of amino acids as eluents in ion chromatography // Anal. Sci., 1985, 1, 335-339.

3. Ivask, J., Pentchuk, J. Application of phenylalanine and tyrosine as eluents in ion chromatography. The effect of eluent concentration and $\mathrm{pH}$ on the retention time of inorganic anions // Proc. Acad Sci. ESSR. Chem., 1989, 38, N 2, 125-129.

4. Haldna, O., Palvadre, R., Pentchuk, J., Kleemeier, T. Preparation of low-capacity anionexchange resin for ion chromatography on a methacrylic copolymer matrix // J. Chromatogr., 1985, 350, 296-298.

5. Snyder, L. R., Kirkland, J. J. Introduction to Modern Liquid Chromatography. New York, Chichester et al., 1979, 22-34.

Academy of Sciences of the Estonian SSR,
Institute of Geology

Received

Jan. 25, 1989

Tartu Sanitation and Hygiene Station

\section{J. IVASK, J. PENTSUK}

\section{FENUOLALANIINI JA TUROSIINI KASUTAMINE ELUENDINA IOONKROMATOGRAAFIAS. ELUENDI KOOSTISOSADE SORBEERUMINE SUPRESSORKOLONNIS}

Uuriti aminohappelise eluendi sorptsiooniprotsesse kationiidil $\mathrm{KY}-2$ ning eluendi komponentide ioonkromatograafilise analüüsi vőimalusi. Fenüülalaniini ja türosiini lahutamiseks ja määramiseks on rakendatav ioonkromatograafia ühekolonniline meetod, kasutades spektrofotomeetrilist detektorit $(\lambda=222 \mathrm{~nm})$ ja $0,5 \mathrm{mM}$ sulfaatset eluenti. Naatriumioonide määramiseks sobib ioonkromatograafia ühekolonniline meetod koos kaudse konduktomeetrilise detekteerimise ning $3 \mathrm{mM}$ lämmastikhappelise eluendiga. Tingimustel, mis kölbavad anorgaaniliste anioonide kvantitatiivseks analüüsiks, sorbeerub supressorkolonnis kogu aminohape, kuid osa eluendi vajaliku $\mathrm{pH}$ saavutamiseks lisatud $\mathrm{NaOH}$-st läbib (ca $0,05 \mathrm{mM}) \mathrm{NaOH}$ lahuse foonil.

\section{Ю. ИВАСК, Я. ПЕНЧУК}

\section{ИСПОЛЬЗОВАНИЕ ФЕНИЛАЛАНИНА И ТИРОЗИНА КАК ЭЛЮЕНТА В ИОННОИ ХРОМАТОГРАФИИ. СОРБЦИЯ КОМПОНЕНТОВ ЭЛЮЕНТА В ПОДАВЛЯЮЩЕИ КОЛОНКЕ}

Подвергнуты исследованию сорбция аминокислотного элюента на катионите КУ-2 и возможности ионохроматографического определения компонентов элюента. Определение сенилаланина и тирозина проведено одноколоночным вариантом ионной хроматографии н ного элюента. Натрий-ионы определены с помощью одноколоночного варианта ионной ента применено с косвенным кондуктометрическим детектированием. В качестве элюента применено 3 мM HNO . Найдено, что в условиях, прнгодных для количественного кислота, но часть ганических анионов, в подавляющей колонке сорбируется вся аминопислота, но часть гидроксида натрия, добавленная для достижения нужной $\mathrm{pH}$ элюента, бавленного $(0,05 \mathrm{~m} M)$ раствора $\mathrm{NaOH}$. 